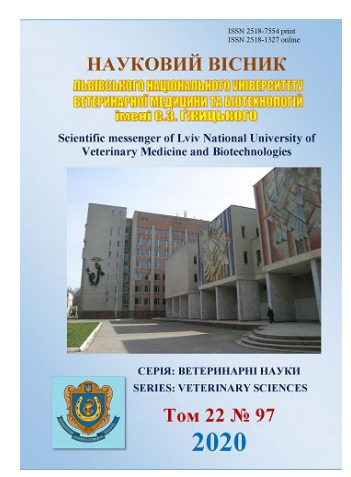

Науковий вісник Дьвівського національного університету ветеринарної медицини та біотехнологій імені С.3. Гжицького. Серія: Ветеринарні науки

Scientific Messenger of Lviv National University of Veterinary Medicine and Biotechnologies. Series: Veterinary sciences doi: $10.32718 /$ nvlvet9703

https://nvlvet.com.ua/index.php/journal

UDC 338.439.021.1

\title{
Species composition and methicillin resistance of staphylococci taken on dairy farms
}

\author{
Y. V. Horiuk ${ }^{1}$, M. D. Kukhtyn², V. Z. Salata ${ }^{3}$, V. V. Horiuk ${ }^{1}$ \\ ${ }^{1}$ State Agrarian and Engineering University in Podilya, Kamjanets-Podilskyi, Ukraine \\ ${ }^{2}$ Ternopil Ivan Puluj National Technical University, Ternopil, Ukraine \\ ${ }^{3}$ Stepan Gzhytskyi National University of Veterinary Medicine and Biotechnologies, Lviv, Ukraine
}

Article info

Received 21.01.2020

Received in revised form 21.02.2020

Accepted 22.02.2020

State Agrarian and Engineering University in Podilya,

Schevchenko Str., 13, Kamianets-

Podilskyi, Khmelnytskyi region,

32300, Ukraine.

Tel.: +38-097-661-79-64

E-mail: goruky@ukr.net

Ternopil Ivan Puluj National Technical University, Department of Food Technologies,

Ruska Str., 56, Ternopil, 46001,

Ukraine.

Stepan Gzhytskyi National University of Veterinary Medicine and Biotechnologies Lviv, Pekarska Str., 50, Lviv, 79010, Ukraine.
Horiuk, Y. V., Kukhtyn, M. D., Salata, V. Z., \& Horiuk, V. V. (2020). Species composition and methicillin resistance of staphylococci taken on dairy farms. Scientific Messenger of Lviv National University of Veterinary Medicine and Biotechnologies. Series: Veterinary sciences, 22(97), 13-19. doi: 10.32718/nvlvet9703

Methicillin-resistant staphylococci can often asymptomatically colonize animals and humans and are capable of causing disease in them. Therefore, their identification and species identification are important for establishing the source of zoonotic infection and the reservoirs of antimicrobial resistance genes. The purpose of the search was to study the spread of methicillin-resistant staphylococci on dairy farms in the Western region of Ukraine. BD Baird-Parker Agar (HiMedia, India) was used to isolate staphylococci. Specific identification of pure cultures was performed using "RapID Staph Plus" kits (Oxord, UK). Staphylococcus sensitivity to methicillin was determined by inoculum application on Muller-Hinton agar with oxacillin (HiMedia, India). The sensitivity of the isolates to antibacterial preparations was determined by disco-diffusion method. The results of our searches show that Staphylococcus aureus is virtually identical in the amount both from cows $(50.1 \%)$ and from humans $(62.4 \%)$. In this case the frequency of its isolation among other species was $20.3 \%$. Along with Staphylococcus aureus there are such species as: S. haemolyticus (20.3\%), S. saprophyticus (13.6\%), S. xylosus (14.0\%), S. chromogenes (11.1\%), S. sciuri (8.8\%), S. epidermidis $(4.8 \%), S$. hominis $(3.4 \%), S$. cohnii $(2.6 \%)$ and $S$. warner $(0.7 \%)$. In this case, approximately the same irradiation of cows, humans and the environment by species $S$. haemolyticus (44.5:70.8:58.8\%), S. epidermidis (12.7:16.6:9.1\%), S. xylosus (26.0:37.4:52.9\%) is observed. The share of $S$. aureus strains on methicillin-resistant dairy farms in the Western Ukraine is $26.8 \%$. The proportion of S. aureus strains on methicillin-resistant dairy farms in the Western Ukraine is $26.8 \%$. Methicillin resistance is also shown S. haemolyticus, S. saprophyticus, S. xylosus ma S. chromogenes. In this case their number is 1.1, 1.3, 1.6 and 5.5 times lower, respectively, and $S$. hominis 1.2 times higher than $S$. aureus. In addition, the selected cultures simultaneously show resistance to two or more antibiotics. Thus, staphylococci circulating on dairy farms are a large reservoir of resistance genes of antimicrobial preparations. Therefore, it is necessary to establish a constant control of the secretion of staphylococci resistant to $\beta$ lactam antibiotics.

Key words: staphylococci, dairy farms, $\beta$-lactam antibiotics, antibiotic resistance.

\section{Видовий склад та стійкість до метициліну стафілококів, виділених на молочних фермах}

\author{
Ю. В. Горюк ${ }^{1}$, М. Д. Кухтин ${ }^{2}$, В. 3. Салата ${ }^{3}$, В. В. Горюк ${ }^{1}$ \\ ${ }^{1}$ Подільський державний аграрно-технічний університет, м. Кам'янець-Подільський, Украйна \\ ${ }^{2}$ Тернопільський національний технічний університет імені I. Пулюя, м. Тернопіль, Украӥна
}




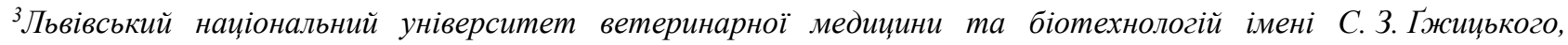
м. Львів, Україна

Стійкі до метициліну стафілококи можуть часто безсимптомно колонізувати тварин та людей $і$ здатні викликати у них захворювання. Тому їх виявлення та видова ідентифікація є важливими для встановлення формування джерела зоонозної інфекиї та резервуарів генів протимікробної стійкості. Мета роботи - вивчити поширення стафілококів стійких до метициліну на молочних фермах Західного регіону України. Для виділення стафілококів використовували BD Baird-Parker Agar (HiMеdia, Iндія). Видову ідентифікацію чистих культур проводили з використанням наборів “RapID Staph Plus” (Oxоіd, Bелика Британія). Чутливість стафілококів до метициліну визначали шляхом нанесення інокуляту на агар Мюллер-Хінтон з оксациліном(НіМедіа, Індія). Чутливість ізолятів до антибактеріальних препаратів визначали диско-дифузійним методом. Результати наших досліджень показують щзо золотистий стафілокок практично в однакових кількостях виділяється, як від корів (50,1%) так і від людей (62,4 \%). При цьому частота його виділення серед інших видів складала 20,3 \%. Поряд з золотистим стафілококом виділяються такі види, як: S. haemolyticus (20,3\%), S. saprophyticus (13,6\%), S. xylosus (14,0\%), S. chromogenes (11,1\%), S. sciuri (8,8\%), S. epidermidis (4,8\%), S. hominis (3,4\%), S. cohnii (2,6\%) та S. warner (0,7\%). При иььому спостерігається приблизно однакове обсіяння корів, людей та навколишнього середовища видами S. haemolyticus (44,5:70,8:58,8\%), S. epidermidis (12,7:16,6:9,1 \%), S. xylosus (26,0:37,4:52,9\%). Частка штамів S. aитеиs на молочних фермах Західного регіону Украӥни, стійких до метициліну, складає 26,8 \%. Також метицилінрезистентність проявляють S. haemolyticus, S. saprophyticus, S. xylosus ma S. chromogenеs. При иьому їх кількість в 1,1, 1,3, 1,6 та 5,5 рази відповідно менша, а S. hотіпіs в 1,2 рази більша порівняно з $S$. аигеиs. Крім того, виділені культури одночасно проявляють резистентність до двох і більше антибіотиків. Отже, стафілококи, які ичикулюють на молочних фермах, являють собою великий резервуар генів резистентності до антимікробних препаратів. Тому необхідно встановити постійний контроль за виділенням стафілококів, стійких до $\beta$-лактамних антибіотиків.

Ключові слова: стафілококи, молочні ферми, $\beta$-лактамні антибіотики, антибіоткорезистентність.

\section{Вступ}

Поява і поширення стійкості до протимікробних препаратів є зростаючою проблемою охорони громадського здоров’я у всьому світі (Sivakumar et al., 2019; Medina et al., 2020). У цьому контексті антибіотикостійкі бактерії у тварин, яких використовують для одержання харчових продуктів, являють собою серйозну загрозу як потенційне джерело інфекцій людини (Horiuk, 2018; Abreu et al., 2019; Medina et al., 2020). Такий зооноз може відбуватися як через прямий контакт з тваринами, так і у процесі виробництва і споживання продуктів тваринного походження (Kukhtyn et al., 2017; Mahdavi et al., 2019; Rahi et al., 2020). Стурбованість викликає не тільки потенційна передача самих резистентних мікроорганізмів, але і горизонтальна передача генів детермінант стійкості від мікрофлори тварини до патогенів людини (Horiuk et al., 2018; Alnakip et al., 2019).

Золотистий стафілокок, особливо стійкий до метициліну $S$. aureus (MRSA), є одним із прикладів антибіотикорезистентного збудника, який циркулює у тваринництві і здатний передаватися людям (Kukhtyn et al., 2017; Locatelli et al., 2017; Johler et al., 2018; Horiuk et al., 2019). Дійсно, S. aureus та MRSA мають широкий діапазон господарів, що сприяє горизонтальній передачі генів та диверсифікації геному ядра (Abreu et al., 2019). MRSA - це резистентність до всіх, крім останнього покоління, антимікробних препаратів $\beta$ лактамного ряду. Ця стійкість виникає завдяки модифікованому білку, що зв'язує пеніцилін (РВР2а), кодованому геном тесA, який переноситься на мобільний генетичний елемент (SCCmec) (Parisi et al., 2016; Alnakip et al., 2019).

Вперше штами $M R S A$, асоційовані 3 домашніми тваринами (LA-MRSA), було виділено у 2005 році (Voss et al., 2005) на регіональних свинокомплексах Європи. Нині MRSA виявлено у широкого кола тварин у багатьох Свропейських країнах та Північній Амери- ці (Haag et al., 2019). Даний патоген може часто безсимптомно колонізувати тварин, проте в окремих випадках здатний викликати інфекції у людей і тварин, включаючи летальні випадки. Ряд досліджень показали, що люди, які контактують 3 домашніми тваринами, мають підвищений ризик колонізації $L A$ $M R S A$. Так, LA-MRSA CC398 був виявлений у 24-86\% свиней, 31-37 \% великої рогатої худоби і 9-37 \% птахів, а також у 44-45 \% ветеринарів, які обслуговували цих тварин (Goerge et al., 2017).

Спостереження за поширенням $L A-M R S A$ у тварин та продуктах харчування є добровільним в Свропейському Союзі, хоча Свропейське агентство з безпеки харчових продуктів (EFSA) рекомендує регулярний нагляд за $L A-M R S A$ у стадах бройлерів, при відгодівлі свиней та молочних фермах. $L A-M R S A$ зараз визнаний третьою епідеміологічною формою $M R S A$ у людей, поряд із асоційованою $C A-M R S A$ (побутовою) та $H A$ $M R S A$ (лікарняною) (Medina et al., 2020).

Дані щодо поширеності $L A-M R S A є$ у всіх країн, які беруть участь у рутинному систематичному спостереженні у щорічних звітах, складених EFSA (Європейським органом з безпеки харчових продуктів та Свропейським центром профілактики та контролю захворювань). Незважаючи на збільшення кількості звітів про циркуляцію $L A-M R S A$ на молочних фермах та в молоці і молочних продуктах Свропи, в Україні в даний час недостатньо даних щодо виділення та структурованого спостереження за LA-MRSA.

Крім того, більшість робіт зосереджують свою увагу на дослідженні $M R S A$, виділених на молочних фермах (Guimaraes et al., 2017; Rahi et al., 2020). Проте, резистентність до метициліну, що кодується тесA та mесC, була описана у широкому діапазоні інших видів стафілококів, знайдених у людей та тварин (Feld et al., 2018; Papadopoulos et al., 2019). Існують повідомлення, про виділення mесA-позитивних Staphylococcus epidermidis, Staphylococcus sciuri, Staphylococcus saprophyticus, Staphylococcus haemolyticus, Staphylo- 
coccus xylosus, Staphylococcus pseudoxylosus, S. saprophyticus (Stefani \& Varaldo, 2003; Van Duijkeren et al., 2004; Hammad et al., 2012). На жаль, у багатьох дослідженнях резистентна до метициліну мікрофлора не ідентифікуються до видового рівня та / або досліджуваної генетичної основи їх стійкості (Ghodasara et al., 2018).

Видова ідентифікація стафілококів, у тому числі ізолятів, стійких до метициліну, на молочних фермах $\epsilon$ потенційно важливим для встановлення формування джерела стійкої зоонозної інфекції та резервуарів генів протимікробної стійкості. Тому метою роботи було вивчити поширення стафілококів, стійких до метициліну, на молочних фермах Західного регіону України.

\section{Матеріал і методи досліджень}

Експериментальні дослідження проводили в лабораторіях Тернопільської дослідної станції Інституту ветеринарної медицини НААН, Подільському державному аграрно-технічному університеті та господарствах Тернопільської, Хмельницької, Чернівецької та Львівської областей.

Для виділення стафілококів використовували BD Baird-Parker Agar (HiMedia, Індія). Культивування проводили за температури $37^{\circ} \mathrm{C}$, результати оцінювали через 24-48 годин. Видову ідентифікацію чистих культур проводили з використанням наборів “RapID Staph Plus" (Oxоid, Велика Британія).

Чутливість стафілококів до метициліну визначали за наступною методикою. Бактеріальну суспензію стафілококу готували 3 декількох колоній з однаковою морфологією на стерильному фізіологічному розчині (3 мл) і доводили до каламутності 0,5 за шкалою McFarland. Далі готували розведення 1:100 стандартного інокуляту і за допомогою мікропіпетки наносили краплю (10 мкл) на поверхню агару МюллерХінтон з оксациліном. У якості контролю використовували агар без оксациліну (HiMedia, Індія).
Чутливість ізолятів до антибактеріальних препаратів визначали диско-дифузійним методом, використовуючи диски 3 антибіотиками (Himedia, Індія). При постановці досліду використовували Mueller Hinton Agar (Himedia, Індія). Приготування мікробних суспензій проводили відповідно до оптичного стандарту мутності 1,0 одиниць за шкалою McFarland з використанням приладу Densi-LaMeter (PLIVA-Lachema Diagnostika, Чехія).

Отримані результати досліджень оброблено статистично 3 використанням програм Microsoft Excel i Statistika 7 Edition, а результати середніх значень вважали вірогідними при $\mathrm{P} \leq 0,05$.

\section{Результати досліджень}

Для того, щоб вивчити поширення стафілококів стійких до метициліну на молочних фермах Західного регіону України нами було досліджено їх видовий склад та частоту виділення окремих видів 3 різних ареалів існування (рис. 1, табл. 1).

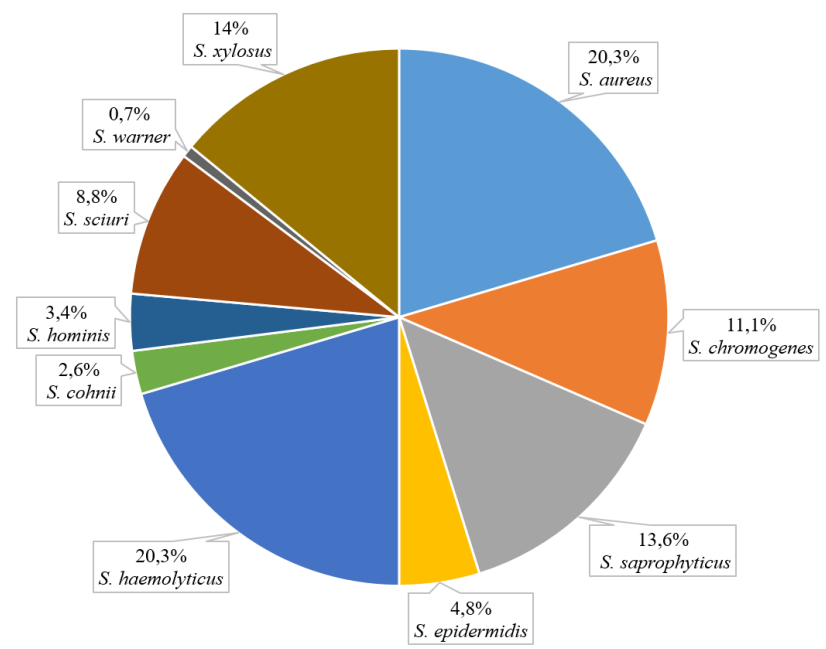

Рис. 1. Видовий склад стафілококів, що циркулюють на молочних фермах Західного регіону України

\section{Таблищя 1}

Частота виділення окремих видів стафілококів, які циркулюють на молочних фермах Західного регіону України

\begin{tabular}{|c|c|c|c|c|c|c|c|c|c|c|c|c|c|c|}
\hline \multirow{3}{*}{ Вид стафілококів } & \multicolumn{14}{|c|}{ Досліджено зразків } \\
\hline & \multicolumn{2}{|c|}{$\begin{array}{l}\text { Шкіра } \\
\text { вимені } \\
\text { корів, } \\
\text { n= } 31\end{array}$} & \multicolumn{2}{|c|}{$\begin{array}{c}\text { Слизові } \\
\text { носа корів, } \\
\text { n }=24\end{array}$} & \multicolumn{2}{|c|}{$\begin{array}{c}\text { Шкіра рук } \\
\text { доярок, } \\
\text { n = } 12\end{array}$} & \multicolumn{2}{|c|}{$\begin{array}{c}\text { Слизові носа } \\
\text { доярок, } \\
\text { n }=12\end{array}$} & \multicolumn{2}{|c|}{$\begin{array}{c}\text { Змиви } 3 \\
\text { доїльного } \\
\text { обладнання, } \\
\text { n }=32 \\
\end{array}$} & \multicolumn{2}{|c|}{$\begin{array}{l}\text { Стічні } \\
\text { води, } \\
\mathrm{n}=17\end{array}$} & \multicolumn{2}{|c|}{$\begin{array}{c}\text { Молоко } \\
\text { сире, } \\
\mathrm{n}=14\end{array}$} \\
\hline & $\mathrm{n}^{1}$ & $\%$ & $\mathrm{n}^{1}$ & $\%$ & $\mathrm{n}^{1}$ & $\%$ & $\mathrm{n}^{1}$ & $\%$ & $\mathrm{n}^{1}$ & $\%$ & $\mathrm{n}^{1}$ & $\%$ & $\mathrm{n}^{1}$ & $\%$ \\
\hline S. aureus & 13 & 41,9 & 14 & 58,3 & 7 & 58,3 & 8 & 66,6 & 2 & 6,2 & 11 & 64,7 & 4 & 28,6 \\
\hline S. chromogenes & 12 & 38,7 & 9 & 37,5 & 0 & 0 & 3 & 25,0 & 0 & 0 & 6 & 54,5 & 1 & 7,1 \\
\hline S. cohnii & 1 & 3,2 & 2 & 8,3 & 1 & 8,3 & 1 & 8,3 & 0 & 0 & 2 & 11,7 & 0 & 0 \\
\hline S. epidermidis & 4 & 12,9 & 3 & 12,5 & 1 & 8,3 & 3 & 25,0 & 1 & 3,1 & 1 & 9,1 & 1 & 7,1 \\
\hline S. haemolyticus & 16 & 51,6 & 9 & 37,5 & 8 & 66,6 & 9 & 75,0 & 3 & 9,4 & 10 & 58,8 & 2 & 14,3 \\
\hline S. hominis & 0 & 0 & 0 & 0 & 6 & 50,0 & 4 & 33,3 & 0 & 0 & 0 & 0 & 0 & 0 \\
\hline S. saprophyticus & 2 & 6,4 & 4 & 16,6 & 9 & 75,0 & 6 & 50,0 & 4 & 12,5 & 12 & 70,6 & 1 & 7,1 \\
\hline S. sciuri & 9 & 29,0 & 6 & 25,0 & 0 & 0 & 0 & 0 & 0 & 0 & 9 & 52,9 & 0 & 0 \\
\hline S. warner & 0 & 0 & 0 & 0 & 0 & 0 & 0 & 0 & 0 & 0 & 2 & 11,7 & 0 & 0 \\
\hline S. xylosus & 7 & 22,9 & 7 & 29,2 & 4 & 33,3 & 5 & 41,6 & 6 & 18,7 & 9 & 52,9 & 0 & 0 \\
\hline
\end{tabular}

Примітка: $\mathrm{n}$ - кількість змивів; $\mathrm{n}^{1}-$ кількість змивів, обсіяних окремими видами стафілококів 
Результати дослідження з визначення видової циркуляції стафілококів на молочних фермах Західного регіону України виявили, що основними представниками роду Staphylococcus були види S. aureus та S. haemolyticus, які виділялися у рівних кількостях (по $20,3 \%)$ При цьому основними їх джерелами були слизові оболонки носа доярок $(66,6$ та 75 \% відповідно). Дещо менша кількість даних видів стафілококів виділялася 3 шкіри рук доярок - 58,3 та 66,6 \%. Біотопом існування даних видів стафілококів також була шкіра вимені та слизові оболонки носа корів. При цьому їх виділяли, в середньому, в 1,4 рази менше, ніж 3 шкіри рук та слизових болонок носа доярок. Доїльне обладнання (до санобробки) можна вважати умовно чистим. Так, $S$. aureus виділений лише у 6,2 , а $S$. haemolyticus у 9,4 \% досліджених змивів. Забруднені проби молока $S$. aureus виявляли у 28,6 \% досліджених зразків. Велику кількість цих видів знайдено і у стічних водах ферми $(58,8-64,7 \%)$.

Одним 3 основних видів стафілококів, які здатні спричиняти мастит корів, $\epsilon$ S. epidermidis. Частка його виділення від корів була в середньому 12,7 \%. При

\section{Таблиця 2}

Частота виділення Staphylococcus spp., стійких до метициліну

\begin{tabular}{lcccc}
\hline \multirow{2}{*}{ Вид стафілококів } & \multicolumn{2}{c}{ Досліджено культур всього } & Кількість культур, стійких до метициліну \\
\cline { 2 - 5 } & $\mathrm{n}$ & $\%$ & $\mathrm{n}$ & \% \\
\hline S. aureus & 56 & 100 & 15 & 4,5 \\
S. chromogenes & 22 & 100 & 1 & 25 \\
S. haemolyticus & 12 & 100 & 3 & 16,6 \\
S. xylosus & 12 & 100 & 2 & 20 \\
S. saprophyticus & 10 & 100 & 2 & 0 \\
S. epidermidis & 8 & 100 & 0 & 0 \\
S. cohnii & 6 & 100 & 2 & 0 \\
S. hominis & 6 & 100 & 0 & 0 \\
S. sciuri & 5 & 100 & 0 & 0 \\
S. warner & 1 & & 0
\end{tabular}

3 даних табл. 2 видно, що майже серед усіх ідентифікованих видів стафілококів виявлялися види стійкі до метициліну, тільки види $S$. epidermidis та $S$. cohnii були у $100 \%$ чутливими до даного антибіотику. Найбільша частка стійких культур була виявлена у виду $S$. hominis - 33,3 \%. Тоді, як $S$. aureus появляв у 1,2 рази меншу стійкість, порівняно з $S$. hominis. цьому даний вид контамінував руки доярок у 8,3\% випадків, а слизові оболонки носа у 3 рази частіше.

Велику кількість сапрофітного стафілококу виявлено на шкірі рук доярок - 75,0 \% досліджених змивів були обсіяні цим видом, тоді, як на шкірі вимені та слизових оболонках носа корів їх було у 11,7 та 4,5 разів менше.

S. chromogenes обсіював вим'я та ніс корів у 37,538,7 \%. При цьому взагалі не виділявся 3 шкіри рук доярок. Стічні води забруднював у 54,5 \% проб.

Приблизно у рівних кількостях від корів виділяли S. sciuri та $S$. xylosus (22,9-29,2 \%). При цьому S. sciuri не контамінував руки та слизові оболонки людей, тоді як S. xylosus виділявся у 33,3-41,6 \% досліджених змивів.

Також нами були ідентифіковані такі види, як S. cohnii та $S$. warner. Незначна кількість $S$. cohnii (до $11,7 \%$ рівномірно обсіювала всі досліджені зразки, окрім змивів $з$ доїльного обладнання, тоді як $S$. warner виділявся лише із стічних вод ферми $(11,7 \%)$.

Наступним етапом дослідження було визначити частоту виділення стафілококів різних видів, стійких до метициліну (табл. 2).

\section{Таблиця 3}

Резистентність стафілококів до антибіотиків, стійких до метициліну

\begin{tabular}{|c|c|c|c|}
\hline Виділена культура & Вид стафілококу & Джерело виділення & Антибіотикорезистентність ${ }^{1}$ \\
\hline Sam-1 & S. aureus & Шкіра рук доярок & $\mathrm{P}, \mathrm{K}, \mathrm{TE}, \mathrm{CTR}$ \\
\hline Sam-2 & S. aureus & Слизова оболонка носа доярок & $\mathrm{P}, \mathrm{K}, \mathrm{EX}, \mathrm{CTR}$ \\
\hline SAm-14 & S. aureus & Шкіра вимені корови & $\mathrm{P}, \mathrm{K}, \mathrm{TE}$ \\
\hline SAm-15 & S. aureus & Слизова оболонка носа корови & $\mathrm{P}, \mathrm{TE}, \mathrm{EX}$ \\
\hline Sch-1 & S. chromogenes & Шкіра вимені корови & $\mathrm{P}, \mathrm{EX}$ \\
\hline Shaem-1 & S. haemolyticus & Слизові оболонки носа доярок & $\mathrm{P}, \mathrm{K}, \mathrm{CTR}$ \\
\hline Sx-1 & S. xylosus & Стічні води & P, TE, CTR \\
\hline Ss-2 & S. saprophyticus & Стічні води & $\mathrm{P}, \mathrm{TE}$ \\
\hline Shom-1 & S. hominis & Шкіра рук доярок & $\mathrm{P}, \mathrm{K}, \mathrm{EX}, \mathrm{CTR}$ \\
\hline
\end{tabular}

Примітка: ${ }^{1}$ визначено стійкість до Р (бензилпеніцилін, $10 \mathrm{U}$ ), К (канаміцин, $\left.30 \mu \mathrm{g}\right), \mathrm{TE}$ (тетрациклін, $\left.30 \mu \mathrm{g}\right), \mathrm{EX}($ енрофлоксацин, $10 \mu \mathrm{g})$, CTR (цефтріаксон, $30 \mu \mathrm{g}$ ) 
3 даних табл. 3 видно що всі культури, які проявляли стійкість до метициліну, були мультирезистентними. Так, 33,3 \% досліджених культур, серед яких були види $S$. aureus та $S$. hominis, проявляли резистентність до чотирьох $з$ пяти досліджених антибіотиків. Стійкими до трьох антибіотиків були 44,4 \% культур, та до двох - 22,2 \% відповідно.

\section{Обговорення}

Здатність до колонізації та спричинення інфекцій у різних господарів, включаючи людей, $є$ важливою характеристикою для S. aureus (Horiuk et al., 2018; Papadopoulos et al., 2019). Використання різних методик дозволило диференціювати штами $S$. aureus на конкретні ековари та біотипи (генетичне походження, клони або лінії), які зазвичай асоціюються 3 конкретними господарями серед ссавців, людей, птиці, собак, великої рогатої худоби тощо (Parisi et al., 2016; Kukhtyn et al., 2017; Horiuk, 2019). Подальші дослідження показали, що деякі лінії стафілококів не обмежені, тобто одні і ті ж самі штами можуть колонізувати або ж спричиняти захворювання у широкого спектру видів, включаючи людину. Наприклад, штам ST1 в основному “людського походження" може спричиняти мастит у BPX (Grundmann et al., 2010). Результати наших досліджень показують, що золотистий стафілокок практично в однакових кількостях виділявся, як від корів (50,1\%), так і від людей $(62,4 \%)$. При цьому частота його виділення серед інших видів складала 20,3\%. Вміст золотистого стафілококу значно варіює на фермах (7-69 \%) різних країн світу. За результатами більшості дослідників ці дані залежали від практик ведення тваринництва, санітарно-гігієнічних заходів на молочних фермах, технологій виготовлення та зберігання молочних продуктів, географічного розташування, методів виділення бактерій тощо. Проте досить мало літератури описує видовий склад стафілококів у середовищі ферми, хоча достеменно відомо, що звичайна сапрофітна мікрофлора може бути потенційним джерелом генів антибіотикостійкості (Guimaraes et al., 2017; Johler et al., 2018; Kovalenko et al., 2018). Наші дослідження виявили досить широкий діапазон стафілококів з різних джерел існування на території молочних ферм. Так, поряд 3 золотистим стафілококом, виділяли такі види як: S. haemolyticus (20,3\%), S. saprophyticus (13,6\%), S. xylosus (14,0\%), S. chromogenes $(11,1 \%)$, S. sciuri $(8,8 \%), S$. epidermidis $(4,8 \%), S$. hominis $(3,4 \%)$, S. cohnii $(2,6 \%)$ та $S$. warner $(0,7 \%)$. При цьому ми спостерігали приблизно однакове обсіяння корів, людей та навколишнього середовища видами S. haemolyticus $\quad(44,5: 70,8: 58,8 \%), \quad$ S. epidermidis (12,7:16,6:9,1\%), S. xylosus (26,0:37,4:52,9\%). Виділення певних видів, що одночасно зустрічаються у корів, обслуговуючого персоналу та в середовищі ферми свідчить про потенціал передачі одних і тих самих бактерій між трьома секторами, а отже і передачі патогенних властивостей, в тому числі і стійкості до антибіотиків (Anker et al., 2018).
Стійкість до $\beta$-лактамних антибіотиків є специфічною патогенною особливістю стафілококів (Locatelli et al., 2017; Normanno et al., 2019). Наше дослідження виявило, що на молочних фермах західного регіону України циркулюють штами $S$. aureus, які проявляють стійкість до метициліну. Їх частка складала 26,8 \% від загальної кількості досліджених культур золотистого стафілококу. При цьому вони були виділені з різних джерел в межах території молочних ферм. Іншими видами стафілококів, які були стійкими до метециліну виявилися $S$. haemolyticus, S. saprophyticus, S. xylosus, та $S$. chromogenes. При цьому їх кількість була в 1,1 , $1,3,1,6$ та 5,5 рази відповідно меншою, а S. hominis в 1,2 рази більшою порівняно з $S$. aureus.

Раніше вченими було описано можливість набувати метицилінрезистентність у $S$. intermedius, S. pseudintermedius та S. schleiferi, які виявлялися від домашніх тварин (Hanselman et al., 2006). Нині також відомі випадки метицилінрезистентності серед коагулазонегативних стафілококів. При цьому SCCmec демонструє більшу поліморфну структуру у стійких до метициліну коагулазонегативних стафілококів (MR-CoNS), $з$ частими комбінаціями ccr-mес, які не описані в $M R S A$, та множинними та / або нетиповими алотипами $c c r$. Елементи $\mathrm{SCC}$, що не містять тесA, були зареєстровані у $S$. heemolyticus та $S$. epidermidis (Barbier et al., 2010).

Крім того, виявлені стафілококи, стійкі до метициліну, були резистентними щонайменше до двох інших антибіотиків. Штами Sam-1, Sam-2 та Shom-1 були нечутливими до чотирьох 3 п'яти досліджених препаратів, SAm-14, SAm-15, Shaem-1 та Sx-1 до трьох, Sch-1 та Ss-2 до двох.

\section{Висновки}

Отже, можна зробити висновок, що різні види стафілококів, які циркулюють на молочних фермах, являють собою великий резервуар генів резистентності до антимікробних препаратів, які в процесі одержання молока можуть його забруднювати та передаватися людям. Тому необхідно встановити постійний контроль за виділенням не лише $M R S A$, але і інших стафілококів, стійких до $\beta$-лактамних антибіотиків.

\section{References}

Abreu, R., Rodríguez-Alvarez, C., Lecuona, M., Castro, B., Gonzalez, J. C., Aguirre-Jaime, A., \& Arias, A. (2019). Increased antimicrobial resistance of MRSA strains isolated from pigs in Spain between 2009 and 2018. Veterinary sciences, 6(2), 1-7. doi: 10.3390/vetsci6020038.

Alnakip, M. E., Quintela-Baluja, M., Böhme, K., Caamaño-Antelo, S., Bayoumi, M. A., Kamal, R. M., \& Barros-Velázquez, J. (2019). Molecular characterisation and typing the methicillin resistance of Staphylococcus spp. isolated from raw milk and cheeses in northwest Spain: A mini survey. International dairy journal, 89, 68-76. doi: 10.1016/j.idairyj.2018.09.006. 
Anker, J. C. H., Koch, A., Ethelberg, S., Molbak, K., Larsen, J., \& Jepsen, M. R. (2018). Distance to pig farms as risk factor for community-onset livestockassociated MRSA CC398 infection in persons without known contact to pig farms. A nationwide study. Zoonoses Public Health, 65(3), 352-360. doi: $10.1111 /$ zph.12441.

Barbier, F., Ruppe, E., Hernandez, D., Lebeaux, D., Francois, P., Felix, B., \& Jeanrot, C. (2010). Methicillin-resistant coagulase-negative staphylococci in the community: high homology of SCCmec IVa between Staphylococcus epidermidis and major clones of methicillin-resistant Staphylococcus aureus. The Journal of infectious diseases, 202(2), 270-281. doi: $10.1086 / 653483$.

Feld, L., Bay, H., Angen, O., Larsen, A. R., \& Madsen, A. M. (2018). Survival of LA-MRSA in Dust from Swine Farms. Ann. Work Expo. Health, 62(2), 147 156. doi: 10.1093/annweh/wxx108.

Ghodasara, S. N., Purohit, J. H., Patel, J. S., Mathapati, B. S., Javia, B. B., Barad, D. B., \& Sindhi, S. H. (2018). Recent Trend in Antibiotic Resistance Pattern of MethicillinResistant Staphylococci from Animal and Human. Indian journal of Veterinary Science \& Biotechnology, 14(1), 8-12. doi: 10.21887/ijvsbt.v14i1.12989.

Goerge, T., Lorenz, M. B., van Alen, S., Hübner, N. O., Becker, K., \& Kock, R. (2017). MRSA colonization and infection among persons with occupational livestock exposure in Europe: prevalence, preventive options and evidence. Veterinary microbiology, 200, 612. doi: 10.1016/j.vetmic.2015.10.027.

Grundmann, H., Aanensen, D. M., Van Den Wijngaard, C. C., Spratt, B. G., Harmsen, D., Friedrich, A. W., \& European Staphylococcal Reference Laboratory Working Group. (2010). Geographic distribution of Staphylococcus aureus causing invasive infections in Europe: a molecular-epidemiological analysis. PLoS medicine, 7(1), 1-15. doi: 10.1371/journal.pmed.1000215.

Guimaraes, F. F., Manzi, M. P., Joaquim, S. F., RichiniPereira, V. B., \& Langoni, H. (2017). Outbreak of methicillin-resistant Staphylococcus aureus (MRSA)associated mastitis in a closed dairy herd. Journal of dairy science, 100(1), 726-730. doi: 10.3168/jds.201611700 .

Haag, A. F., Fitzgerald, J. R., \& Penadés, J. R. (2019). Staphylococcus aureus in Animals. Gram-Positive Pathogens, 731-746. doi: 10.1128/9781683670131.ch46.

Hammad, A. M., Watanabe, W., Fujii, T., \& Shimamoto, T. (2012). Occurrence and characteristics of methicillin-resistant and susceptible Staphylococcus aureus and methicillin-resistant coagulase-negative staphylococci from Japanese retail ready-to-eat raw fish. Int. J. Food Microbiol., 156(3), 286-289. doi: 10.1016/j.ijfoodmicro.2012.03.022.

Hanselman, B. A., Kruth, S. A., Rousseau, J., Low, D. E., Willey, B. M., McGeer, A., \& Weese, J. S. (2006). Methicillin-resistant Staphylococcus aureus colonization in veterinary personnel. Emerging infectious diseases, 12(12), 1933-1938. doi: 10.3201/eid1212.060231.
Horiuk, Y. V. (2019). Lytic Activity of Staphylococcal Bacteriophage on Different Biotypes of Staphylococcus aureus. Scientific Messenger of LNU of Veterinary Medicine and Biotechnologies. Series: Veterinary Sciences, 21(94), 115-120. doi: 10.32718/nvlvet9421.

Horiuk, Y. V., Kukhtyn, M. D., Strayskyy, Y. S., Havrylianchyk, R. Y., Horiuk, V. V., \& Fotina, H. A. (2018). Comparison of the minimum bactericidal concentration of antibiotics on planktonic and biofilm forms of Staphylococcus aureus: Mastitis causative agents. Research Journal of Pharmaceutical, Biological and Chemical Sciences, 9(6), 616-622.

Horiuk, Yu., Kukhtyn, M., Kovalenko, V., Kornienko, L., Horiuk, V., \& Liniichuk, N. (2019). Biofilm formation in bovine mastitis pathogens and the effect on them of antimicrobial drugs. Independent Journal of Management \& Production, 10(7), 897-910. doi: 10.14807/ijmp.v10i7.1012.

Horiuk, Yu. V., Kukhtyn, M. D., Perkiy, Yu. B., \& Horiuk, V. V. (2018). Distribution of main pathogens of mastitis in cows on dairy farms in the western region of Ukraine. Scientific Messenger of Lviv National University of Veterinary Medicine and Biotechnologies, 20(83), 115-119. doi: 10.15421/nvlvet8322.

Horiuk, Y. V. (2018). Fagotherapy of cows mastitis as an alternative to antibiotics in the system of obtaining environmentally safe milk. Scientific Messenger of LNU of Veterinary Medicine and Biotechnologies. Series: Veterinary Sciences, 20(88), 42-47. doi: $10.32718 /$ nvlvet 8807 .

Johler, S., Macori, G., Bellio, A., Acutis, P.L., Gallina, S., \& Decastelli, L. (2018). Short communication: Characterization of Staphylococcus aureus isolated along the raw milk cheese production process in artisan dairies in Italy. J. Dairy Sci., 101(4), 2915-2920. doi: 10.3168/jds.2017-13815.

Kovalenko, V. L., Kovalenko, P. L., Ponomarenko, G. V., Kukhtyn, M. D., Midyk, S. V., \& Horiuk, Y. V. (2018). Changes in lipid composition of Escherichia coli and Staphylococcus areus cells under the influence of disinfectants Barez $\AA$, Biochlor $\AA$ and Geocide ${ }^{\circledR}$. Ukrainian Journal of Ecology, 18, 8(1), 547550. doi:10.15421/2018 248.

Kukhtyn, M. D., Horyuk, Y. V., Horyuk, V. V., Yaroshenko, T. Y., Vichko, O. I., \& Pokotylo, O. S. (2017). Biotype characterization of Staphylococcus aureus isolated from milk and dairy products of private production in the western regions of Ukraine. Regulatory Mechanisms in Biosystems, 8(3), 384388. doi: 10.15421/021759.

Locatelli, C., Cremonesi, P., Caprioli, A., Carfora, V., Ianzano, A., Barberio, A., Morandi, S., Casula, A., Castiglioni, B., Bronzo, V. (2017). Occurrence of methicillin-resistant Staphylococcus aureus in dairy cattle herds, related swine farms, and humans in contact with herds. Dairy Sci., 100(1), 608-619. doi: 10.3168/jds.2016-11797.

Mahdavi, F., Zaboli, F., \& Khoshbakht, R. (2019). Characteristics of Erythromycin Resistance in MethicillinResistant Staphylococcus aureus Isolated From Raw 
Milk. International Journal of Enteric Pathogens, 7(4), 121-125. doi: 10.15171/ijep.2019.25.

Medina M., Legido-Quigley H., \& Hsu L. Y. (2020) Antimicrobial Resistance in One Health. In: Masys A., Izurieta R., Reina Ortiz M. (eds) Global Health Security. Advanced Sciences and Technologies for Security Applications. Springer, Cham. doi: 10.1007/978-3030-23491-1_10.

Normanno, G., Spinelli, E., Barlaam, A., Parisi, A., Tinelli, A., \& Capozzi, L. (2019). MethicillinResistant Staphylococcus aureus (MRSA) in Food of Animal Origin: A New Challenge in Food Safety? EC Microbiology, 15(6), 449-454.

Papadopoulos, P., Angelidis, A. S., Papadopoulos, T., Kotzamanidis, C., Zdragas, A., Papa, A., \& Sergelidis, D. (2019). Staphylococcus aureus and methicillinresistant S. aureus (MRSA) in bulk tank milk, livestock and dairy-farm personnel in north-central and north-eastern Greece: Prevalence, characterization and genetic relatedness. Food microbiology, 84, 103249. doi: 10.1016/j.fm.2019.103249.

Parisi, A., Caruso, M., Normanno, G., Latorre, L., Sottili, R., Miccolupo, A., \& Santagada, G. (2016). Prevalence, antimicrobial susceptibility and molecular typing of methicillin-resistant Staphylococcus aureus (MRSA) in bulk tank milk from southern Italy. Food microbiology, 58, 36-42. doi: 10.1016/j.fm.2016.03.004.
Rahi, A., Kazemeini, H., Jafariaskari, S., Seif, A., Hosseini, S., \& Safarpoor Dehkordi, F. (2020). Genotypic and Phenotypic-Based Assessment of Antibiotic Resistance and Profile of Staphylococcal Cassette Chromosome mec in the Methicillin-Resistant Staphylococcus aureus Recovered from Raw Milk. Infection and drug resistance, 13, 273-283. doi: 10.2147/IDR.S229499.

Sivakumar, M., Dubal, Z. B., Kumar, A., Bhilegaonkar, K., Kumar, O. R. V., Kumar, S., \& Dwivedi, A. (2019). Virulent methicillin resistant Staphylococcus aureus (MRSA) in street vended foods. Journal of food science and technology, 56(3), 1116-1126. doi: 10.1007/s13197-019-03572-5.

Stefani, S., \& Varaldo, P. E. (2003). Epidemiology of methicillin-resistant staphylococci in Europe. Clinical microbiology and infection, 9(12), 1179-1186. doi: 10.1111/j.1469-0691.2003.00698.x.

Van Duijkeren, E., Box, A. T. A., Heck, M. E. O. C., Wannet, W. J. B., \& Fluit, A. C. (2004). Methicillinresistant staphylococci isolated from animals. Veterinary microbiology, 103(1-2), 91-97. doi: 10.1016/j.vetmic.2004.07.014.

Voss, A., Loeffen, F., Bakker, J., Klaassen, C., \& Wulf, M. (2005). Methicillin-resistant Staphylococcus aureus in pig farming. Emerging infectious diseases, 11(12), 1965-1966. doi: 10.3201/eid1112.050428. 